\title{
Travelling With Heart: Role of Wanderlust Indonesia as a Creative Travel Provider
}

\author{
Novita Indah Mulyaningrum \\ Hotel Management and Tourism \\ Sekolah Tinggi Pariwisata Bogor \\ Bogor, Indonesia \\ novita.mulyaningrum@gmail.com
}

\author{
Deari Hanifa Karismawandri \\ Tours and Travel Business \\ Sekolah Tinggi Pariwisata Bogor \\ Bogor, Indonesia \\ karismawandri@gmail.com
}

\begin{abstract}
Travel provider has important role as tourism service tool. Most travel providers have intention to contribute advancing tourism destination by offering the most appealing tour package. This study aims to understand the role of Wanderlust Indonesia as one of the travel providers who accommodates creative responsible travel package for its "Wanderer". As a creative travel provider, Wanderlust Indonesia organized exceptional travel experiences. Creative responsible travel planned by Wanderlust Indonesia has becoming the development tool for improving the livelihood and preserving the tourism destination environment. The research method applied is qualitative method with in-depth interview towards Wanderlust Indonesia and their customer base to seek for Wanderlust Indonesia role as creative travel provider. Findings of this study are Wanderlust Indonesia as a creative travel provider has contributed making a change by change the way of people travel and responsible traveler awareness has been successfully formed during the program. As conclusion, Wanderlust Indonesia role to create creative tour package which concern on responsible travel experience with extraordinary pleasure has becoming the travel alternative choice.
\end{abstract}

Keywords - creative tourism, creative travel provider, responsible tourism

\section{INTRODUCTION}

Tourismhas become one of the most dynamically developing industries around the world. Mowforth explained that"New inventions have made travel an affordable practice and have massively increased the number of tourists who represent a broad spectrum of social classes." (cited in Strzelecka, 2012, p.1). Nowadays, tourism in Indonesia has not been categorized as complement necessary, but the role has been move onto primary one. Growth of tourism demand has led to tourism development becoming a new high priority goal for many countries, including Indonesia.

Indonesia has a lot of potential tourism destinations with various attractions from beach, forest, mountain, village and others. Ministry of Tourism of The Republic of Indonesia (2016) found that there were around 8.3 million international travelers have visited Indonesia per September 2016 (p.2). That potential fact indicated that Indonesia has an active tourism activities every year and millions travelers have been born from the tourism activities. Tourism industry development has various supporting tools to accommodate the process, one of the most important tourism service tools is travel provider. Selecting the most reliable travel provider has becoming the primary choice decided before the trip was started, since one of the trip convenience factor depended on the interesting scheduled activities provided by the travel provider. Most of travel providers competed to offer the most appealing tour package in purpose to attract travelers in several unique ways. The most creative program arranged to satisfy travelers in the most exceptional trip experiences.

Richards (2011) explained that, "The practice of tourism currently involves the '4Ps' of creativity, such as: creative person, the creative process, the creative product, and the creative environment." (p.1226). As stated by Ray that creativity becomes an instrument for development of communities, cities, and regions in a search for growth. But also on a personal level, creativity becomes a strategy to promote innovation and individual skill development (cited in Huras, 2015, p.8). Tourism is in turn one of the major carriers of economic growth in the field of culture and creativity. Richards (2011) found that "People seem increasingly keen to develop their creative potential, by enhancing their productive or consumption skills, by following courses or experiencing creativity on holiday." (p.1225). This bright value idea has been successful to attract traveler participated in responsible tourism in the most creative way.

The travelers who visited tourism site have different habit and behavior, it implied from the way travelers react and connect with local people. It also becomes prior concern since human behavior has detected unpredictable and resulted in various responses. Unfortunately, the irresponsible traveler who leaves not only footprints in the tourism site but also trash or worse, disturbance and damage to the tourism site has been exposed viral in the social media. The saddest part is the punishment has not been existed towards the travelers act yet, none of the reckless travelers be responsible for what they did which disturbed the tourism site environment. Some of them only received public humiliation as their ethic violation, while the real problem happened towards the tourism environment has not been handled seriously. Some of travel providers who concerned on this issue have proposed responsible tourism programs on their exquisite tour package. The innovation in 
tourism has led travel providers to create creative responsible travel program as the most appealing alternative preference.

\section{LITERATURE REVIEW}

As stated by Ray that creativity becomes an instrument for development of communities, cities, and regions in a search for growth. But also on a personal level, creativity becomes a strategy to promote innovation and individual skill development (cited in Huras, 2015, p.8). "In underdeveloped communities there is a need to support the economy by fostering the strengths of the area, promoting activities that engage young people, but also reinforcing culture and creativity that induce community participation, and build social connection between people of different backgrounds, capacities, and ages (Huras, 2015, p.1). Based on Richards (2011), "The practice of tourism currently involves the creative person, the creative process, the creative product, and the creative environment." (p.1226). "People seem increasingly keen to develop their creative potential, by enhancing their productive or consumption skills, by following courses or experiencing creativity on holiday." (Richards, 2011, p.1225).

UNESCO (2006) stated:

"Creative Tourism is travel directed toward an engaged and authentic experience, with participative learning in the arts, heritage, or special character of a place, and it provides a connection with those who reside in this place and create this living culture". (as cited in Jana, J., \& Marián, H, 2012, p.5).

Creative tourism supply starts from the stance that creativity rather than mindlessness is the objective of being a tourist, at least for part of a tourism trip, and possibly for all of a person's time away from home. Indeed, this may apply to some package tourists, who may be re-conceptualized as wanting choice and the opportunity to develop interests. While Raymond (2007) defined creative tourism, as follow:

"Creative tourism as a sustainable form of tourism that offers authentic experiences of local culture using informal and practical seminars and creative experiences. Seminars take place in little groups in the households and workplaces of instructors. Visitors have the opportunity to discover their own creativity and get more involved with local people." (as cited in Jana, J., \& Marián, H, 2012, p.5).

Bourgeon-Renault (2005) found that "Key to creative tourism supply is the recognition that tourists (and others) contribute to their own product, by their cultural capital, expertise, experience, emotions and the like." (as cited in Prentice, R., \& Andersen, V, 2007, p.91).

Creative tourism resulted creative product and services as the outcome and its objective pointed at local community prosperity and local business success surround the tourism destination site. Ohridska-Olson (2010) developed a Creative Tourism Business Model with supporting 5 groups of element factors which authors adopted as a conceptual framework for this research shown in Figure 1 and the concept definition of each dimension will be explained in Table 1 .
On the other hand, Jana, J., \& Marián, H (2012) found that, "Creative tourisms have common elements: authenticity of experiences that enable visitors to develop their creative potential and their skills by means of contact with local people and their culture. Such a form of tourism prefers active consumption over passive consumption. It emphasizes life and intangible culture, not static tangible cultural heritage. Creative tourism is based on activities and experiences that offer selfrealization and self-expression. Tourists thus become cocreators and develop their creative abilities." (p.5).

According to creative tourism, travel provider operating both locally as well as nationally and internationally, should be encouraged to provide tourism products in the country. Goldblatt, J. \& Nelson, S. (2001) stated, "The travel agencies are defined as a firm qualified to arrange for travel-related retail services on behalf of various tourism industry principals." (cited in Pastiuet al., 2014, p.328).

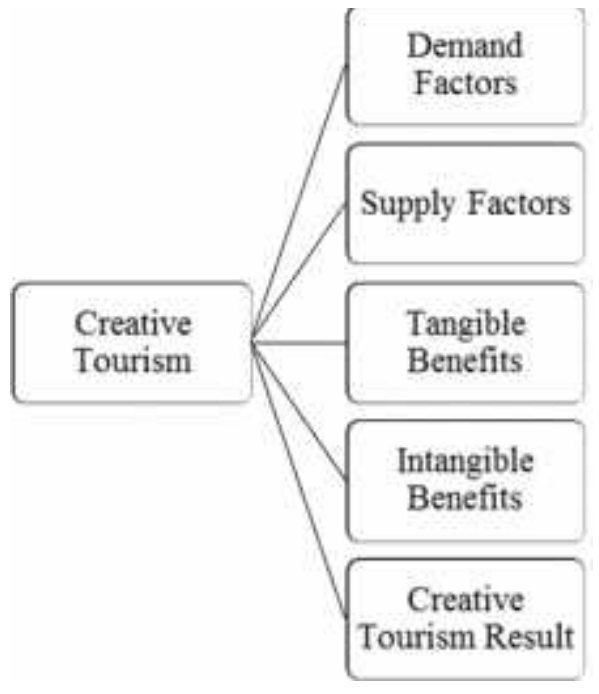

Fig. 1. Creative Tourism Business Model

Pastiuet al. (2014) found the role of travel agencies in tourism development, as following:

"Travel agencies have a great power to influence anddirect consumer demand comparing to other industries; Travel agencies are not just intermediaries, they act like as an interface between supply and different segments of demand; Modern travel agencies have many different forms and very complex relationships.” (p.329)

Pointing at the travel agencies role mentioned above, indicated that travel agency is an important part among other tourism service tool. Becoming the preeminent travel agency could lead not only as trend setter in the market but also as successful profit gainer. Selecting the appropriate travel provider currently becoming one of traveler's tough decision, especially nowadays in the middle of modern world.

The travel provider framing in this research has unique character by prioritizing responsible tourism in their tour package. The most important thing in responsible tourism is the practices educate travelers about the social and environmental 
impact of their decisions, showing how travel can be a potent form of diplomacy, and giving travelers a forum through which their united voices can serve the world community. Weeden (2013) stated," The responsible tourism concept focused on minimization of interference in the natural environment, respect for cultural diversity, maximization of local people participation in providing tourist services, increasing customer satisfaction and satisfaction of tourists." (as cited in Dębicka, O. \& Oniszczuk-Jastrząbek, A., 2014, p. 191).

TABle I. Creative Tourism Business Model

\begin{tabular}{|c|c|c|}
\hline Element of Creative Tourism & Concept Definition & Factors of Element \\
\hline Demand Factors & $\begin{array}{l}\text { Demand factors are factor that make the tourist feeling } \\
\text { needed and having willingness to travel }\end{array}$ & $\begin{array}{l}\text { Participation in culture and creativity, Cultural Heritage } \\
\text { Preservation and Authenticity, Human Interaction and Cultural } \\
\text { Immersion, Cultural travel and tourism }\end{array}$ \\
\hline Supply Factors & $\begin{array}{l}\text { Supply factors are availability of destination which can } \\
\text { providing something as required by the tourists }\end{array}$ & $\begin{array}{l}\text { Global cultural diversity, Unique local cultural offerings and } \\
\text { unique local arts and crafts, Tourism infrastructure, cultural } \\
\text { tourism resources, hospitality and other types of tourism, } \\
\text { Creative tourism products and services }\end{array}$ \\
\hline Tangible Benefits & $\begin{array}{l}\text { Benefits that can be quantified and improves the } \\
\text { productivity of process }\end{array}$ & $\begin{array}{l}\text { Cultural capital, Market expansion, Innovation, Cultural } \\
\text { heritage preservation, Sustainability, Brand visibility, Job } \\
\text { creation, Exports }\end{array}$ \\
\hline Intangible Benefits & $\begin{array}{l}\text { Subjective attitudes and perceptions that can't be } \\
\text { expressed by money. Intangible benefits are gains } \\
\text { attributable to project improvement that are not reportable } \\
\text { for formal accounting purposes }\end{array}$ & $\begin{array}{l}\text { Local identity and uniqueness, Social capital, Cultural values } \\
\text { preservation, Global human interaction and cultural exchange, } \\
\text { Local cultural diversification }\end{array}$ \\
\hline Creative Tourism Result & $\begin{array}{l}\text { Result of creative tourism which is considered a new } \\
\text { generation of tourism by involving the tourists themselves } \\
\text { and the locals in creation with the opportunity to connect }\end{array}$ & $\begin{array}{l}\text { Local business success enhancement and local community } \\
\text { prosperity enhancement because of the services and products } \\
\text { supplied by the local residents, sense of pride and } \\
\text { satisfactionenhancement in the community. }\end{array}$ \\
\hline
\end{tabular}
with local people in a distinctive destination

According to Stanford (2006), the total definition of responsible tourism as follow:

"Responsible tourism covers all forms of tourism, alternative and mass alike; secondly, it embraces a quadruple bottom line philosophy to contribute to and enhance local communities, cultures, environments and economies and minimize negative impacts in these areas; and thirdly, it benefits all those involved." (p.42)

\section{METHODS}

The method used for this research is qualitative method and main data technique collected by in depth-interview. The interview was conducted on 12 people which consisted of 1 person as a Co-founder of Wanderlust Indonesia, 1 person as a Leader of Ranger (Wanderlust Indonesia staff) and 10 people are short and long trip's Wanderers (Wanderlust Indonesia's customers). The interview period was on $17^{\text {th }}-20^{\text {th }}$ October 2016. The interview purpose is to determine their expectations and experiences on the services provided by Wanderlust Indonesia. The collected data from in-depth interview will be interpreted with Phenomenology approach by finding people experience essential or phenomenon happened caused by the experience and represented by descriptive technique (data were explained and described per each dimension stated in conceptual framework to give an overview of the phenomenon). The categorization of data obtained from the literature study. Conclusion based on the purpose of research. The conclusions drawn from the research result.

\section{RESULT AND DISCUSSION}

The result of this research based on in depth-interview technique with Creative Tourism Business Model elements analysis, which had several elements such as demand factors, supply factors, intangible benefits, tangible benefit and creative tourism result. Regarding to demand factors which had creativity, human interaction, cultural heritage preservation and brand visibility for its indicators, Wanderlust Indonesia has provided creative and unique tour package as expected as the customer demands and also supported in connecting the relationship between each traveler and local community surround the tourism destination site. On the other hand, they have been known to encourage the traveler in exploring hidden heritage in certain tourism destination site by keeping the cleanliness of its destination and purchasing local products from local community surround the destination. At the final, for brand visibility, by joining into Wanderlust Indonesia tour package made the travelers capable to recognize traditional local product produced by local community surround the tourism destination site.

As for the supply factors, Wanderlust Indonesia's original idea to create creative tour package based on the existence of unique local cultural potential surround the tourism destination site which needed to be empowered and developed indicating their unique local cultural offering. Furthermore, there was no successful in creating exceptional tour package without any hospitality factor, so that being the hospitable person in the program process has becoming one of the key success of Wanderlust Indonesia in the field. However, one of the most important resources during Wanderlust tour package was 
contribution of local tourism infrastructure surround the tourism destination site which supported in the process by providing the local guide during the trip and the supportive local facilities, such as accommodations, transportation and other local attraction services.

Based on research that has been done, Wanderlust Indonesia also had intangible and tangible benefits, which relative into the conceptual framework. The Wanderers (Wanderlust Indonesia's customer), have known the local community identity and their uniqueness which was different from each destination and this information indirectly upgrading their knowledge regarding the tourism destination itself and during the program offered by Wanderlust Indonesia, they had opportunity to exchange their culture with local community surround the tourism destination site and encourage the traveler to explore hidden heritage in certain tourism destination site. Apart from that, project development of Wanderlust Indonesia in certain tourism destination site has been formed in purpose to preserve their local cultural values. As the tangible benefits, Wanderlust Indonesia contributing in different and unique tour package not only expanding personal creativity skill, but also increasing innovation in tourism field. It also has shown onto various unique tour package selection offered by Wanderlust Indonesia. Moreover, following all scheduled trip from Wanderlust Indonesia has been successfully preserve the cultural heritage surround the tourism destination site and based on relationship with local community, it has been shown that their pride and sense of belonging as local community were noticeable. Finally, the Wanderers appreciated the program made by Wanderlust Indonesia and planning to acknowledge themselves more in responsible tourism field.

According to several elements stated above, the creative tourism result based on this research shown by the successful of Wanderlust Indonesia introducing their creative tour package which concern on responsible travel experience with extraordinary pleasure has becoming the travel alternative choice among travel.

\section{CONCLUSION}

According to the result, there are some conclusions for this research, for instance: Wanderlust Indonesia roles in creating responsible tourism-based tour package has becoming travel alternative choice. The authentic tour packages offered by Wanderlust Indonesia has encouraged Wanderers (Wanderlust Indonesia's customers) to expand their communication skill with new environment during their trip to specific tourism destination and also motivate the travelers to contribute to the local community by teaching some subjects, innovate local library in the tourism site, clean up the environment surround the tourism destination and other possible activities performed in tourism destination. Wanderlust Indonesia also facilitate the fund-raising activity organized to contribute computers or books or other educational donation to improve local community surround the tourism destination, furthermore, Wanderlust Indonesia promoted local community business by assisting to sell their product through Wanderlust Indonesia official social media with buyer target who live outside the tourism destination site. In short, Wanderlust Indonesia contributed to synergize traveler's awareness towards the tourism destination site as the responsible travel practice embodiment.

\section{REFERENCES}

Dębicka, O. \& Oniszczuk-Jastrząbek, A. (2014). Responsible Tourism in Poland. Proceedings of Biennial International Congress Tourism \&Hospitality Industry, 22, 189-202.

Huras, C. (2015). Community-Based Creative Tourism as a Strategy for Poverty Reduction. Taipei National University of the Arts. Taiwan.

Jana, J., \& Marián, H. (2012). Creativity and Rural Tourism. Creative and Knowledge Society, 2, 5-15.

Ministry of Tourism of The Republic of Indonesia. (2016). International Visitor Arrivals by Port of Entry and Nationality, Retrieved from: http://www.kemenpar.go.id/userfiles/file/Lapbul\%20Sep\% 202016_eng.pdf

Ohridska-Olson, R., \& Ivanov, S. (2010). Creative Tourism Business Model And Its Application In Bulgaria, Proceeding of the

Black Sea Tourism Forum: Cultural Tourism The Future of Bulgaria.

Pastiu, C., Muntean, A., Moisa, C., \& Maican, S. (2014). The Role Of Travel Agencies In Tourism Development In Alba County, Proceedings of Biennial International Congress Tourism \&Hospitality Industry, 22, 327-337.

Prentice, R., \& Andersen, V. (2007). Creative tourism supply: Creating culturally empathetic destinations. In Richards, G. \& Wilson, J. (Ed.), Tourism. Creativity and Development (p.91), New York: Routledge Taylor \& Francis Group.

Richards, G. \& Wilson, J. (Eds). (2007). Tourism. Creativity and Development. New York: Routledge Taylor \& Francis Group.

Richards, G., (2011).Creativity and Tourism: The State of The Art. Annals of Tourism Research, (Vol. 38) No. 4, 12251253.

Stanford, D. (2006). Responsible Tourism, Responsible Tourists: What makes a responsible tourist in New Zealand?, (Unpublished doctoral dissertation). Victoria University of Wellington, New Zealand.

Strzelecka, M. (2012). Individual and Community Empowerment Enhancement in Sustainable Tourism Development in Post-Communist Poland, (Unpublished doctoral dissertation). University of Illinois at UrbanaChampaign, Illinois. 